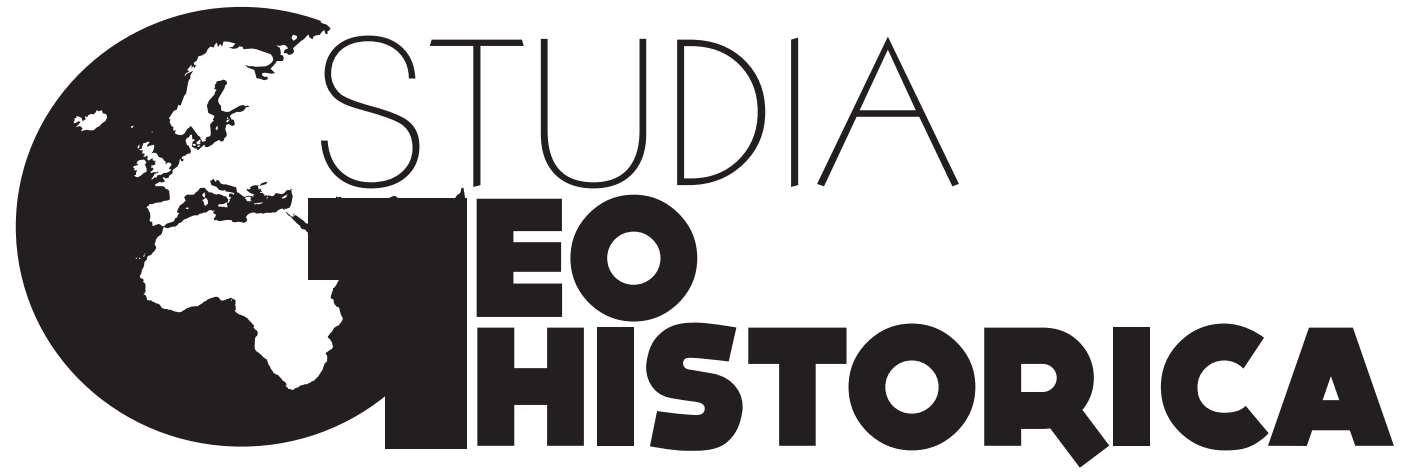

NR 04|2016 ROCZNIK HISTORYCZNO-GEOGRAFICZNY

Fundacja Centrum GeoHistorii • Instytut Geodezji i Kartografii • Instytut Historii KUL

Instytut Historii i Stosunków Międzynarodowych US • Zespół Historii Kartografii przy Instytucie Historii Nauki PAN Biblioteka Główna Uniwersytetu Szczecińskiego 


\section{STUDIA GEOHISTORICA. Rocznik historyczno-geograficzny}

\section{Redakcja}

Bogumił Szady (redaktor naczelny), Beata Konopska, Radosław Skrycki, Tomasz Związek (sekretarz redakcji), Tomasz Panecki

\section{Redakcja językowa i korekta}

Konrad Byzdra

\section{Tłumaczenia}

autorzy, Julia Szołtysek

\section{Rada Naukowa}

Zdzisław Budzyński (Rzeszów), Andrzej Janeczek (Warszawa), Tomasz Jurek (Poznań), Keith Lilley (Belfast/Wielka Brytania), Andrew Pernal (Brandon/Kanada), Tadeusz Siwek (Ostrawa/Czechy), Rostysław Sossa (Kijów/Ukraina), Grzegorz Strauchold (Wrocław), Robert Šimůnek (Praga/Czechy)

\section{Recenzenci tomu 4}

Wojciech Chudziak, Martyna Deszczyńska, Zbigniew Górczak, Maria Jankowska, Iwona Jażdżewska, Andrzej Klonder, Anna Kołodziejczyk, Andrzej Kopiczko, Małgorzata Elżbieta Kowalczyk, Adam Kozak, Joanna Kumor-Mielnik, Mieczysław Kunz, Dariusz Lorek, Wojciech Mielewczyk, Grzegorz Myśliwski, Wiesław Nowosad, Piotr Pabjanek, Marek Radoch,

Małgorzata Rutkiewicz-Hanczewska, Francesco Somaini, Péter Szabó, Piotr Werner, Filip Wolański

\section{Redakcja map}

autorzy, Tomasz Panecki

\section{Adres Redakcji}

Fundacja Centrum GeoHistorii

Redakcja Studia Geohistorica

05-082 Stare Babice, ul. Gen. Tadeusza Kutrzeby 4

\section{Strona internetowa}

studiageohistorica.pl

Wersja drukowana (papierowa) jest wersją pierwotną rocznika Studia Geohistorica

\section{Współwydawcy rocznika}

Biblioteka Główna Uniwersytetu Szczecińskiego, Fundacja Centrum GeoHistorii, Instytut Geodezji i Kartografiii, Instytut Historii Katolickiego Uniwersytetu Lubelskiego Jana Pawła II, Instytut Historii i Stosunków Międzynarodowych Uniwersytetu Szczecińskiego, Zespół Historii Kartografii przy Instytucie Historii Nauki PAN

Rocznik wydawany pod patronatem Komisji Geografii Historycznej przy Polskim Towarzystwie Historycznym Projekt okładki: Jacek Młodożeniec Ilustracja na okładce: Kalisz - Plan miasta i przyległej okolicy autorstwa Ludwiga von Bröckera z 1802 r. Skład i łamanie: Artur Hamryszczak

(C) Copyright by Fundacja Centrum GeoHistorii

ISSN 2300-2875

Nakład 100 egz.

Warszawa 2016 


\section{Spis treści • Contents}

\section{Tradycje geografi historycznej • Traditions of historical geography}

\section{Ludomir Sawicki}

Geografia a krajoznawstwo

(uwagi wstępne Beata Konopska, opracowanie Beata Konopska)

\section{Stanisław Herbst}

Prace nad „Atlasem historycznym Polski”

(uwagi wstępne Henryk Rutkowski, opracowanie Henryk Rutkowski).

\section{Artykuty $\bullet$ Articles and theses}

\section{Elżbieta Kowalczyk-Heyman}

Czym były mazowieckie "płozy"? (uwagi wstępne)

What were the Masovian "płozy"? (Preliminary Remarks)

\section{Robert Klimek}

Ślady średniowiecznej granicy Warmii między Reszlem a Świętą Lipką

Traces of the Medieval Border of Warmia between Reszl and Święta Lipka

\section{Ewa Ziółek}

Relacja Grzegorza Piramowicza o osuszaniu Bagien Pontyjskich za pontyfikatu Piusa VI

Grzegorz Piramowicz's Account of Draining the Pontian Marshes during

the Pontificate of Pope Pius VI

\section{Krzysztof Boroda}

Wpływy z czopowego jako wskaźnik lokalnego zróżnicowania poziomu produkcji

piwa pełnego w miastach Królestwa Polskiego w latach 60. XVI w.

Income from Czopowe as an Indicator of Regional Diversity of Full Beer

Production in the Cities of the Polish Crown in the 1560s

\section{Xavier Rochel}

The End of Gaps and Heathlands in French National Forests, $19^{\text {th }}$ Century.

A Case Study Based on Forest Management Plans

Zanik polan i wrzosowisk we francuskich lasach państwowych w XIX w.

Studium przypadku na podstawie planów zarządzania lasami

\section{Tomasz Figlus}

Typy morfogenetyczne wsi w środkowej Polsce

Morphogenetic Types of Rural Settlements in Central Poland. 
Tomasz Babczyński, Tomasz Kubik, Roman Ptak, Grzegorz Strauchold GIS as a Tool to Analyze the History of Silesia and the Changes in its Political (and Cultural) Geography GIS jako narzędzie do analizy historii Śląska oraz zmian w jego geografii politycznej i kulturowej..

\section{Mateusz Zawadzki}

"Tabella miast, wsi i osad Królestwa Polskiego" jako źródło do badań nad strukturą parafialną województwa lubelskiego

The "Tabella of Towns, Villages and Settlements of the Kingdom of Poland" as the Source for Research into the Parochial Structure of the Lublin Voivodeship

Anna Paulina Orłowska, Bartosz Nowożycki, Grzegorz Pac Handel wołami na terenie Wielkopolski i Śląska w świetle szesnastowiecznego spisu jarmarków i komór celnych The Trade in Oxen on the Territory of the Greater Poland and Silesia in the Light of the $16^{\text {th }}$ Century Description of Annual Fairs and Toll Houses

\section{Recenzje i omówienia $・$ Reviews and discussions}

Historical Atlas of Poland in the $2^{\text {nd }}$ half of the $16^{\text {th }}$ Century: Voivodeships of Cracow, Sandomierz, Lublin, Sieradz, Łęczyca, Rawa, Płock and Mazovia, ed. by Marek Słoń; transl. by Agata Staszewska; Martha A. Brożyna, Peter Lang Edition, Frankfurt am Main 1973-[2014], 4 volumes, XXIX + 1597 pp., illustrations, 27 folded maps

(Alexei Frolov)

Magdolna Szilágyi: On the Road: The History and Archaeology of Medieval Communication Networks in East-Central Europe, Budapest 2014

(Archeolingua Series Minor, 35),

Ss. 254, 89 il. (w tym 30 map i 4 plany miast)

(Ewelina Siemianowska).

The World in a Mirror, Word Maps from the Middle Ages to the Present Day, ed. Jan Parmentier, Museum aan de Stroom, Antwerp 2015, ss. 192, il. $150+25$ (Lucyna Szaniawska)

Kartografia morska i krain nadmorskich, red. R. Skrycki, Instytut Historii

i Stosunków Międzynarodowych Uniwersytetu Szczecińskiego,

Zespół Historii Kartografii Instytutu Historii Nauki PAN, Szczecin 2014;

$24 \times 17$ cm, ss. 204, 54 ryc., 4 tab.

(Jan Rutkowski) 
Алексей А. Фролов, Нина В. Пиотух: Исторический атлас Деревской пятины Новгородской земли (по писцовым книгам письма 1495-1496 годов). В 3 томах: Москва-Санкт-Петербург, Альянс-Архео, 2008.

Т. 1: Исследование и таблицы, ss. 368;

Т. 2: Атлас и справочные материалы, ss. 272;

T. 3: Уездные планы последней четверти XVIII века, ss. 266

(Rostysław Sossa).

Nazwy miejscowe Polski. Historia. Pochodzenie. Zmiany, t. 10-12 (Ra-Rż), red. K. Rymut, B. Czopek-Kopciuch, U. Bijak, [autorzy haseł: U. Bijak, E. Borysiak, J. Chłądzyńska, B. Czopek-Kopciuch, P. Dudek, A. Galasińska, W. Makula-Kosek, I. Nobis, R. Przybytek, P. Swoboda, U. Wójcik, K. Zawodzińska-Bukowiec, Z. Zierhoffer], Polska Akademia Nauk. Instytut Języka Polskiego, Kraków 2015, ss. 160 (t. 10), 146 (t. 11), 168 (t. 12) (Ewa Oronowicz-Kida).

Kit Mayers: The First English Explorer. The Life of Anthony Jenkinson (1529-1611) and his Adventures on Route to the Orient, Devon 2015, ss. 366

(Krystyna Szykuła).

\section{Komunikaty $i$ sprawozdania $\bullet$ Communiques and reports}

Konferencja „Przestrzenne aspekty historycznych badań demograficznych, społecznych i gospodarczych (do 1945 r.)" - Pobierowo, 21-23 października 2015 r.

(Michał Gochna)

„European Social Science History Conference” - Walencja (Hiszpania),

30 marca-2 kwietnia $2016 \mathrm{r}$.

(Michał Gochna)

Zebranie naukowe polskiej sekcji European Society for Environmental History - Warszawa, 16 stycznia $2016 \mathrm{r}$.

(Piotr Guzowski)

„Mapa jako narracja interpretacyjna”. XXIX Ogólnopolska Konferencja Historyków Kartografii - Wrocław, 24-26 września $2015 \mathrm{r}$.

(Jerzy Ostrowski)

Sprawozdanie z konferencji „Województwo poznańskie w XVI w.” - Kościan, 1 lipca 2015 r.

(Michał Stomski).

Sprawozdanie z konferencji „Geografia historyczna. Wyzwania przyszłości” - Łódź, 11-12 czerwca 2015 r.

(Magdalena Deptuła). 204 
Spis treśsi

Pro memoria

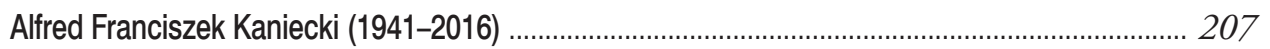

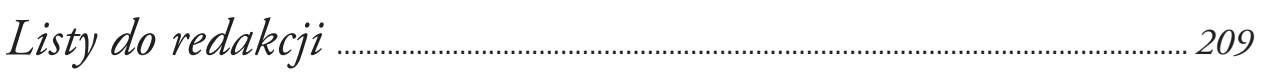

Informacja dla autorów • Guidelines for Authors .................................................... 210 


\title{
„Tabella miast, wsi i osad Królestwa Polskiego" jako źródło do badań nad strukturą parafialną województwa lubelskiego
}

\author{
Mateusz Zawadzki
}

Głównym celem niniejszego artykułu jest geograficzno-historyczna i statystyczna analiza zmierzająca do oceny przydatności Tabelli miast, wsi $i$ osad Królestwa Polskiego ${ }^{1}$ (dalej: Tabella) jako źródła do badań nad strukturą parafialną. Pojęcie parafia pojawia się tu zamiennie z terminem okreg parafialny. Wynika to z faktu, iż rozważania dotyczą aspektu przestrzennego (parafia jako określone terytorium), co sytuuje zakres problematyki w kategorii badań geograficzno-historycznych. Strukture parafialna należy tu rozumieć jako terytorialne rozmieszczenie parafii. Termin filia parafialna będzie stosowany zamiennie z określeniami filia i kościót filialny. Tabella nie zawiera informacji odnośnie do filii parafialnych, a zagadnienie ich istnienia zostanie jedynie zasygnalizowane $\mathrm{w}$ aspekcie weryfikacji przedstawionych w źródle informacji o przynależności parafialnej konkretnych miejscowości. Kwestie organizacyjne (prawnoustrojowe) dotyczące wewnętrznej budowy parafii oraz jej funkcjonowania zostaną tutaj pominięte, gdyż wykraczają poza ramy opracowania. Przedmiotem analizy nie będą też granice dekanatów, ponieważ źródło nie zawiera informacji o przynależności dekanalnej parafii. Tabella zostanie skonfrontowana z Topograficzną Karta Królestwa

\footnotetext{
${ }^{1}$ Tabella miast, wsi, osad Królestwa Polskiego, z wyrażeniem ich położenia i ludności, alfabetycznie ułożona w Biórze Kommissyi Rządowéy Spraw Wewnętrznych i Policyi, Warszawa 1827, t. 1: A-t, ss. 288; t. 2: $M-Z$, ss. 339. Źródło dostępne online w Bibliotece Cyfrowej - Regionalia Ziemi Łódzkiej (http://bc.wimbp.lodz.pl/dlibra/doccontent?id=17882, http:// bc.wimbp.lodz.pl/dlibra/doccontent?id=17883, dostęp: 18 lipca 2016).

2 Topograficzna karta Królestwa Polskiego, 1822-1843, skala 1:126 000. Mapa dostępna online w Cyfrowej Bibliotece Narodowej (https://polona.pl/ item/3742198/1/, dostęp: 19 lipca 2016).

3 Wybór tego źródła podyktowany jest faktem, iż jest to mapa najbliższa Tabelli pod względem czasu powstania. B. Krassowski, Topograficzna karta Królestwa Polskiego (1822-1843), Warszawa 1978, s. 9.
}

Polskiego ${ }^{2}$, czyli tzw. mapą Kwatermistrzostwa ${ }^{3}$. Zabieg ten umożliwi rekonstrukcję granic parafii i będzie przydatny w analizie przestrzennej okręgów parafialnych. Pomocniczo, w celu zweryfikowania informacji wykorzystane zostaną opracowania i źródła chronologicznie bliskie Tabelli: Obraz jeograficzno-statystyczny Królestwa Polskiegó, „Rocznik Instytutów Religijnych i Edukacyjnych w Królestwie Polskim"s oraz współczesne wydawnictwa: Atlas historyczny (archi)diecezji lubelskiej i Sieć dekanalna i parafialna (archi)diecezji lubelskiej w latach 1805-2005.

Artykuł nie ma ambicji wyczerpania podjętego tematu. Wyniki analiz przybliżą nas jedynie do odpowiedzi na pytanie dotyczące przydatności państwowego źródła, jakim jest Tabella, w badaniach struktur Kościoła łacińskiego. Będzie to punkt wyjścia do dalszych rozważań nad użytecznością źródła w aspekcie zmienności terytorialnej struktur parafialnych w XIX w.

Badania mające na celu odtworzenie struktur parafialnych podejmowane były w polskiej historiografii niejednokrotnie ${ }^{8}$. Należy tutaj wspomnieć choćby o pracach prowadzonych w Zakładzie Atlasu Historycznego Polski Instytutu Historii Polskiej Akademii Nauk ${ }^{9}$. Zagadnienia podziałów administracji kościelnej

\footnotetext{
${ }^{4}$ F. Rodecki, Obraz jeograficzno-statystyczny Królestwa Polskiego, Warszawa 1830.

5 „Rocznik Instytutów Religijnych i Edukacyjnych w Królestwie Polskim”, 2, 1826-1827.

${ }^{6}$ Atlas historyczny (archi)diecezji lubelskiej 1805-2010, red. H. Gapski, Lublin 2011.

7 J. Kumor-Mielnik, Sieć dekanalna i parafialna (archi)diecezji lubelskiej w latach 1805-2005, Lublin 2011.

${ }^{8}$ Przedstawiony stań badań nie jest całościowy i ogranicza się głównie do ważniejszych publikacji dotyczących Lubelszczyzny.

${ }^{9}$ W serii „Atlas historyczny Polski. Mapy szczegółowe XVI wieku” ukazały się dotąd: t. 3: Województwo lubelskie w drugiej połowie XVI wieku, oprac.
} 
poruszane były w studiach Instytutu Geografii Historycznej Kościoła w Polsce KUL ${ }^{10}$ przemianowanego 1 czerwca 2010 r. na Ośrodek Badań nad Geografią Historyczną Kościoła w Polsce KUL ${ }^{11}$. Prace badawcze nad zagadnieniem struktur kościelnych prowadzone są również przez Pracownię Geoinformacji Historycznej ${ }^{12}$ działającą przy Instytucie Historii $\mathrm{KUL}^{13}$. Tematyce historii administracji kościelnej poświęcili swe rozważania także Bolesław Kumor ${ }^{14}$ oraz Marek Tomasz Zahajkiewicz ${ }^{15}$.

W dotychczasowych badaniach zauważalny jest brak przedstawienia okręgów parafialnych diecezji lubelskiej z 1. poł. XIX w. Wyniki prac prowadzonych w ramach Atlasu historycznego archi(diecezji) lubelskiej zawężają się dla tego okresu do sieci dekanalnej, odnosząc się wyłącznie do liczby i rozmieszczenia parafii. Wynika to zapewne z braku kościelnych źródeł systematycznych, które prezentowałyby okręgi parafialne, np. schematyzmów lub wizytacji ${ }^{16}$.

Najmniejszą jednostką terytorialną i organizacyjną Kościoła katolickiego była i jest parafia. W okresie, który możemy nazwać przedgminnym, pełniła ona również istotną funkcję w podziale administracyjnym kraju ${ }^{17}$. Korelacja pomiędzy kościelną i państwową administracją terytorialną została zapoczątkowana na ziemiach polskich już w XII w. Stanisław Arnold, powołu-

S. Wojciechowski, Warszawa 1966; t. 7: Mazowsze w drugiej połowie XVI wieku, oprac. W. Pałucki i in., Warszawa 1973; t. 2: Województwo sandomierskie w drugiej połowie XVI wieku, oprac. W. Pałucki i in., Warszawa 1993; t. 5: Województwo sieradzkie i województwo tęczyckie w drugiej połowie XVI wieku, oprac. H. Rutkowski i in., Warszawa 1998; t. 1: Województwo krakowskie w drugiej połowie XVI wieku, oprac. H. Rutkowski i in., Warszawa 2008.

${ }^{10}$ Należy tutaj wymienić związane z instytutem osoby, których wkład jest nie do przecenienia w aspekcie badań nad administracją Kościoła łacińskiego w Polsce: Jerzego Kłoczowskiego, Stanisława Litaka, Wiesława Müllera, Eugeniusza Wiśniowskiego, Jana Skarbka i Henryka Gapskiego. Przegląd najważniejszych prac prowadzonych w instytucie zob. m.in.: S. Litak, Struktura terytorialna Kościoła łacińskiego w Polsce w 1772 roku, Lublin 1980; tenże, Kościót taciński w Rzeczpospolitej około 1772 roku. Struktury administracyjne, Lublin 1996; tenże, Atlas Kościoła łacińskiego w Rzeczpospolitej Oboiga Narodów w XVIII wieku, Lublin 2006.

${ }^{11} 0$ Ośrodku Badań nad Geografią Historyczną Kościoła w Polsce zob. http:// www.kul.pl/0-osrodku,art_129.html (dostęp: 28 lipca 2016 r.). Publikacje traktujące 0 podziałach administracyjnych na obszarze województwa lubelskiego to m.in. Atlas historyczny (archi)diecezji; J. Kumor-Mielnik, Sieć.

${ }^{12}$ Z najważniejszych pozycji należy wspomnieć obszerną publikację Bogumiła Szadego: B. Szady, Geografia struktur religijnych i wyznaniowych w Koronie w II połowie XVIII w., Lublin 2010 (dostępna także online: jąc się na bullę z 1136 r., twierdzi, iż podział kościelny oparł się na zrębie organizacji polityczno-administracyjnej. Dalej dowodzi za Władysławem Semkowiczem, że administracja kościelna miała takie same granice jak państwowa ${ }^{18}$. Stan ten był prawdopodobnie wynikiem naturalnego rozwoju struktur kościelnych. Odmienna sytuacja istniała w XIX w., kiedy w celach administracyjnych władza polityczna rozpoczęła proces dostosowywania granic jednostek kościelnych do państwowych. W tym czasie wprowadzono wiele istotnych zmian w strukturze terytorialnej Kościoła łacińskiego. 18 marca 1817 r. car Aleksander I wydał dokument, na mocy którego oddano Kościół pod nadzór Komisji Rządowej Wyznań Religijnych i Oświecenia Publicznego (dalej: KRWRiOP). Władzom kościelnym zabroniono dokonywać modyfikacji sieci parafialnej, a wszelkie zmiany polegające na erygowaniu nowych parafii lub korygowaniu dotychczasowych granic wymagały zezwolenia rządu ${ }^{19}$. Oficjalnie dostosowania struktury organizacji kościelnej do podziału administracyjnego kraju dokonał na życzenie władz Królestwa Polskiego papież Pius VII bullą Ex imposita nobis z 30 czerwca 1818 r. Diecezja lubelska została włączona do metropolii warszawskiej, a jej obszar pokrywał się odtąd z granicami administracyjnymi województwa lubelskiego ${ }^{20}$. 9 marca 1819 r.

http://www.kul.pl/files/845/pdf/szady_geografia_struktur_2010.pdf; mapa: http://hgisb.kul.lublin.pl/azm/pmapper-4.2.0/map_default.phtml?r esetsession $=\mathrm{ALL} \&$ config $=$ wyznaniowa\&language $=\mathrm{pl}$, dostęp: 20 lipca 2016).

${ }^{13} \mathrm{http}: / /$ hgis.kul.pl (dostęp: 28 lipca 2016).

${ }^{14}$ B. Kumor, Granice metropolii i diecezji polskich (968-1939), Lublin 1971; tenże, Ustrój i organizacja Kościoła polskiego w okresie niewoli narodowej 1772-1918, Kraków 1980.

${ }^{15}$ Archidiecezja Lubelska: historia i administracja, red. M.T. Zahajkiewicz, Lublin 2000; Dzieje Archidiecezji Lubelskiej (1805-2005), red. M.T. Zahajkiewicz, Lublin 2005.

${ }^{16}$ Pełny wykaz źródeł i opracowań dla XIX w. znajduje się w monografii Joanny Kumor-Mielnik: J. Kumor-Mielnik, Sieć, s. 271-297.

${ }^{17}$ H. Kotłątaj, Listy Anonima i prawo polityczne narodu polskiego, oprac. B. Leśnodorski, H. Wereszczycka, t. 2, Kraków 1953, s. 141; S. Litak, Parafie w Rzeczpospolitej w XVI-XVIII wieku, Lublin 2004, s. 10.

${ }^{18} \mathrm{~S}$. Arnold, Terytorja plemienne w ustroju administracyjnym Polski Piastowskiej (w. XII-XIII), Kraków 1927, s. 17.

${ }_{19}$ „Dziennik praw Królestwa Polskiego", 6 (22-27), 1820, s. 242-249.

${ }^{20}$ Zasięg omawianego $\mathrm{w}$ artykule województwa lubelskiego odnosi się do podziału administracyjnego Królestwa Polskiego z 16 stycznia $1816 \mathrm{r}$. Pod względem terytorialnym w dobie Królestwa Kongresowego województwo stanowito odpowiednik departamentu z czasu Księstwa Warszawskiego. 
KRWRiOP nakazała dokonać nowego podziału diecezji na dekanaty, które miały się pokrywać z granicami obwodów i obejmować po $10-18$ kościołów parafialnych ${ }^{21}$.

Rekonstrukcji okręgów parafialnych Kościoła rzymskokatolickiego na obszarze województwa lubelskiego ${ }^{22}$ dokonano na podstawie Tabelli. Wydany w 1827 r. dokument prezentuje wyniki spisu ludności i domów z lat 1824-1826 23 . Omawiane źródło zostało opracowane przez oddział statystyczny Komisji Rządowej Spraw Wewnętrznych, Duchownych i Policji z siedzibą w Warszawie i zawiera spis alfabetycznie ułożonych miejscowości z informacją o ich położeniu geograficznym, określeniem państwowej przynależności administracyjnej miejscowości do województwa, obwodu i powiatu oraz kościelnej-do konkretnej parafii. Tabella jako materiał spisowy zawiera również niezwykle cenne dane na temat: rodzaju własności miejscowości, liczby domów i ogólnej populacji. Dodatkową informacją w aspekcie geograficznym jest określenie odległości danej miejscowości od miasta obwodowego wyrażonej w milach pocztowych ${ }^{24}$. Ten oficjalny urzędowy wykaz nie doczekał się jak dotąd rzetelnego opracowania krytycznego ${ }^{25}$.

W celu zweryfikowania dotychczasowego stanu badań odnośnie do struktury parafialnej die-

Zostały wtedy zniesione powiaty, a w ich miejsce wprowadzono 0 wiele większe obwody. Nazewnictwo i obszar powiatów zachowano, jednak spełniały one już tylko rolę okręgów wyborczych dla sejmików szlacheckich oraz okręgów sądowych. W. Ćwik, J. Reder, Lubelszczyzna: dzieje rozwoju tenytorialnego, podziatów administracyjnych i ustroju władz, Lublin 1977 s. 83; A. Borkiewicz, W. Trzebiński, Podziaty administracyjne Królestwa Polskiego w okresie 1815-1918 r., Warszawa 1956, s. 6 (Dokumentacja Geograficzna, 4).

${ }^{21}$ Atlas historyczny (archi)diecezii, s. 76-78.

${ }_{22}$ Artykuł jest pokłosiem przedsięwzięcia zrealizowanego przy Pracowni Geoinformacji Historycznej KUL w ramach projektu „HISTORYCZNY GIS dla Lubelszczyzny. Projekt rekonstrukcji granic administracji państwowe i kościelnej województwa lubelskiego z 1827 r." (http://hgis.kul.pl/projekty, dostęp: 27 lipca 2016).

${ }^{23}$ Na podstawie dotychczasowych badań ustalenie dokładnego roku, do którego odnoszą się dane zawarte w źródle, nie jest możliwe. Prawdopodobnie dotyczą jednak lat 1822-1825. Na taką cezurę wskazują dwa fakty: 1. 0k 1822 r. zmodyfikowano granice dwóch dekanatów: urzędowskiego i zaklikowskiego. W urzędowskim znalazły się takie parafie, jak: Annopol (filia), Borów, Dzierzkowice, Gościeradów, Księżomierz (filia) i Świeciechów. Do zaklikowskiego przyłączono natomiast: Batorz, Blinów (filia), Bożą Wolę (filia), Frampol (filia), Goraj i Radzięcin. Zmiany te mają odzwierciedlenie w opartym na Tabelli Obrazie jeograficzno-statystycznym. 2. Druga data wynika z faktu, iż w 1826 r. nastąpiła wymiana parafii między dekanatem cezji lubelskiej w zakresie rzeczowym krytycznej ocenie zostaną poddane informacje o przynależności parafialnej miejscowości. Według ustaleń z Atlasu historycznego (archi)diecezji lubelskiej w 1818 r. liczyła ona 12 dekanatów, 127 parafii i 16 filii $^{26}$. Dokładnie taki podział dekanalny przetrwał do $1867 \mathrm{r}^{27}$ Sieć parafialna nie zmieniła się zaś do 1831 r., gdyż w latach 1818-1831 nie erygowano w diecezji żadnej nowej parafii ${ }^{28}$. Odnosząc się do powyższych badań, można stwierdzić, iż w czasie powstania Tabelli sytuacja była pod tym względem stabilna. Omawiane źródło podaje, że na obszarze województwa lubelskiego znajdowało się 1537 miejscowości. Na mapie Kwatermistrzostwa udało się zlokalizować 1411 z nich i posłużyły one jako przedmiot rozważań zmierzających do rekonstrukcji struktury parafialnej oraz analizy treści źródła.

Istotne znaczenie dla poprawności procesu wnioskowania ma próba weryfikacji toponomastycznej występujących w źródle nazw parafii ${ }^{29}$. W niektórych przypadkach pojawiają się tam różne warianty dla tej samej miejscowości parafialnej ${ }^{30}$. Oprócz przypadków powszechnego używania dwóch wersji nazwy miejscowości odmienne formy nazewnicze były prawdopodobnie skutkiem niestarannych zapisów oraz błędów drukarskich. Ich unifikacja możliwa

chełmskim (oddał parafie Surhów i Tarnogóra) a krasnostawskim (oddał Łańcuchów i Skierbieszów). Obraz jeograficzno-statystyczny nie odnotował tego faktu. J. Kumor-Mielnik, Sieć, s. 122-123; Obraz jeograficzno-statystyczny, s. 8.

${ }^{24} 1$ mila pocztowa $=8534 \mathrm{~m}$

${ }^{25}$ C. Domański, A. Jędrzejczak, Rozwój statystyki tódzkiej, Łódź 2015, s. 23; Historia Polski w liczbach. Ludność. Terytorium, Warszawa 1994, s. 53; A. Jelonek, Ludność miast i osiedli typu miejskiego na ziemiach Polski od 1810 do 1960 r., Warszawa 1967, s. 16 (Dokumentacja Geograficzna, 3-4).

${ }^{26}$ Atlas historyczny (archi)diecezji, s. 103.

${ }^{27}$ Tamże, s. 70; B. Kumor, Diecezja lubelska (180 lat istnienia), ,,Wiadomości Diecezjalne Lubelskie", 59 (5-7), 1985, s. 237; tenże, Granice metropolii i diecezji polskich (966-1939), „Archiwa, Biblioteki i Muzea Kościelne”, 20, 1970, s. 331

${ }^{28}$ Atlas historyczny (archi)diecezji, s. 146.

${ }^{29} \mathrm{U}$. Wójcik, 0 sposobach badania nazw własnych (przesztość, teraźniejszość, przyszłość), „Prace Naukowe Akademii im. Jana Długosza w Częstochowie. Językoznawstwo", 11, 2015, s. 160.

${ }^{30}$ Tematyce nazw miejscowych, ich zmian oraz występowania różnych form nazewniczych poświęcony jest artykuł Ewy Rzetelskiej-Feleszko. E. Rzetelska-Feleszko, Nazwy miejscowe, w: Polskie nazwy własne. Encyklopedia, red. E. Rzetelska-Feleszko, Warszawa-Kraków 1998, s. 191-230. 
była dzięki zastosowaniu analizy przestrzennej na bazie mapy Kwatermistrzostwa oraz wykorzystaniu Mapy taktycznej Polski Wojskowego Instytutu Geograficznego ${ }^{31}$. Dla przykładu w omawianym czasie równolegle funkcjonowały nazwy Parczew i Parczów $w^{32}$. Osobnych badań wymaga brak precyzji w zapisie pojawiających się w Tabelli wariantów nazw poszczególnych miejscowości, przede wszystkim parafialnych. Doskonałym przykła- dem jest tutaj toponim Niedrzwica Kościelna ${ }^{33}$, który w analizowanym źródle występuje jako: Niedźwiedzica ${ }^{34}$, Niedźwica ${ }^{35}$ i Niedźwiedzia $M{ }^{36}$. Kolejnymi przykładami są nazwy miejscowości parafialnych: Sieciechów - gdy poprawna nazwa wydaje się brzmieć Świeciechów ${ }^{37}$; Chodywańce - zapisane również jako: Chodowanie, Chodowańce ${ }^{38}$ i Chodowance ${ }^{39}$. Wybrane nazwy oraz próba ich unifikacji zostały zaprezentowane

Tab. 1. Unifikacja nazw własnych parafii na wybranych przykładach ${ }^{40}$

\begin{tabular}{|l|l|}
\hline \multicolumn{1}{|c|}{ Nazwa w Tabelli } & \multicolumn{1}{c|}{ Nazwa po ujednoliceniu } \\
\hline Abramów & Abramowice \\
\hline Biała Wié́ & Biała \\
\hline Chodowanie & Chodywańce \\
\hline Chodowańce & Chodywańce \\
\hline Klimontowice & Klementowice \\
\hline Łosieniec & tosiniec \\
\hline Łuszczow & Łaszczów \\
\hline Miechów & Michów \\
\hline Nadbroż & Nabróż \\
\hline Niedźwiedzia Mała & Niedrzwica Kościelna \\
\hline Niedźwiedzica & Niedrzwica Kościelna \\
\hline Parczów & Parczew \\
\hline Pieski & Piaski \\
\hline Sieciechów & Świeciechów \\
\hline Suchowola & Sucha Wola \\
\hline Targowiska & Targowisko \\
\hline
\end{tabular}

Źródło: „Tabella”, t. 1-2, passim; „Mapa taktyczna Polski”, skala 1:100 000, 1924-1939

\footnotetext{
${ }^{31}$ Mapa taktyczna Polski, skala 1:100 000, 1924-1939, arkusze obejmujące województwo lubelskie z $1816 \mathrm{r}$. W procesie identyfikacji materiału onomastycznego pomocne są opracowania historyczno-językowe czy współczesne spisy i wykazy miejscowości z tenytorium Polski. J. Tyszkiewicz, Geografia historyczna. Zarys problematyki, Warszawa 2014, s. 44-45.

${ }^{32}$ Stownik geograficzny Królestwa Polskiego i innych krajów stowiańskich [dalej: SGKP], t. 7, red. B. Chlebowski, W. Walewski, Warszawa 1886, s. 863; K. Rymut, Nazwy miast Polski, Wrocław-Warszawa-KrakówGdańsk-tódź 1987, s. 180; S. Warchoł, Nazwy miast Lubelszczyzny, Lublin 1964, s. 154-155.

${ }^{33}$ Miejscowość występowała również pod nazwami: Niedrwica, Nedrwicza, Nyedrwiczka i Niedrzwica Mała. S. Wojciechowski, Atlas historyczny Polski. Województwo lubelskie $w$ drugiej połowie XVI wieku, Warszawa 1966, s. 39; Stownik historyczno-geograficzny ziem polskich
}

w średniowieczu, red. T. Jurek (http://www.slownik.hpan.edu.pl/search. php?id=10209, dostęp: 17 października 2016).

${ }^{34}$ Tabella, t. 2, s. 187.

${ }^{35}$ Tamże, s. 43.

${ }^{36}$ Tamże, t. 1 , s. 86.

${ }^{37}$ Na obszarze województwa lubelskiego nie występowała w tym czasie miejscowość Sieciechów.

${ }^{38}$ Według słownika Nazwy miejscowe Polski zmiana formy Chodowańce w Chodywańce jest niejasna. Nazwy miejscowe Polski: historia, pochodzenie, zmiany, red. K. Rymut, t. 2: C-D, Kraków 1997, s. 58.

${ }^{39}$ Tamże, t. 1, s. 66 i 172; t. 2, s. 320.

${ }^{40}$ W kolumnie Nazwa $w$ „Tabelli" podane są przykłady błędnych nazw parafii w źródle. Kolumna Nazwa po ujednoliceniu to próba ujednolicenia ich przez autora na podstawie danych z Mapy taktycznej Polski WIG. 
w tabeli 1 . Bez wnikliwej analizy procesu powstawania źródła nie można wyrokować o dokładnej proweniencji różnic nazewniczych. Poszerzone studia powinny zmierzać w kierunku badań zakresu oboczności geograficznych w stosowanym w źródle nazewnictwie.

Po ujednoliceniu nazw parafii ich liczba została oszacowana na 170 . Jest to wynik wyższy niż ustalony dotychczas w historiografii i wskazany przez źródła zbliżone chronologicznie do Tabellit ${ }^{41}$. Wśród 170 parafii odnotowanych przez źródło znajduje się 12 ośrodków określanych dotąd w badaniach jako filie parafialne $e^{42}$. Zostały one zaprezentowane $\mathrm{w}$ tabeli 2 wraz $\mathrm{z}$ informacją o liczbie i nazwie przynależnych do nich miejscowości.

Nie wszystkie kościoły filialne występujące w dotychczasowych opracowaniach ${ }^{43}$ są ujęte w Tabelli jako parafie. W przypadku Księżomierza (parafia Dzieżkowice) ${ }^{44}$, Ratoszyna (Chodel ${ }^{45}$, Czernięcina (Turobin) ${ }^{46}$ oraz Annopola ${ }^{47}$ określone są jako miejscowości niebędące stolicą

Tab. 2. Wykaz ośrodków filialnych występujących w „Tabelli” jako okręgi parafialne

\begin{tabular}{|l|c|l|}
\hline \multicolumn{1}{|c|}{ Filia podana jako parafia } & $\begin{array}{c}\text { Liczba miejscowości } \\
\text { należących do parafii }\end{array}$ & \multicolumn{1}{c|}{ Wykaz miejscowości } \\
\hline Blinów & 3 & Blinów, Blizów, Moczydło \\
\hline Boża Wola & 5 & $\begin{array}{l}\text { Boża Wola, Dębina, Studzianki, } \\
\text { Studziańska Wola, Węglinek }\end{array}$ \\
\hline Firlej & 2 & Firley, Serock \\
\hline Frampol & 6 & Dyle, Frampol, Kąty, Rzeczyca, Sokotówka, Stara Wieś \\
\hline Karczmiska & 2 & Karczmiska, Stotwiny \\
\hline Kluczkowice & 2 & Kluczkowice, Wrzelowiec \\
\hline Komarów & 7 & $\begin{array}{l}\text { Huta Komarowska, Janówka, Komarów, } \\
\text { Komarów (dwie sąsiadujące miejscowości), } \\
\text { Krzywostok, Księzostawy, Wola Brzozowa }\end{array}$ \\
\hline Krężnica Jara & 6 & $\begin{array}{l}\text { Krężnica Jara, Osmolice, Prawiedniki, } \\
\text { Strzeszkowice, Trzeszkowice, Żabia Wola }\end{array}$ \\
\hline Łuszczów & 1 & Łuszczów \\
\hline Nielisz & 10 & $\begin{array}{l}\text { Białobrzegi, Deszkowice, Gruszka Mała, Gruszka } \\
\text { Wielka, Kitów, Kulików, Nawóz, Nielisz, Średnie, Staw }\end{array}$ \\
\hline Rzeczyca Ziemiańska & 1 & Łychów \\
\hline Wojciechów & 6 & Gay, Łubnik, Maszki, Miłocin, Palikije, Wojciechów \\
\hline
\end{tabular}

Źródło: „Tabella”, t. 1-2, passim; „Obraz jeograficzno-statystyczny”, s. 6

${ }^{41}$ Liczbę 127 parafii podają dotychczasowe opracowania oraz źródła, na których autor opiera się w porównaniach.

${ }^{42}$ Kwestia kościołów filialnych została szeroko opisana w monografii Stanisława Litaka. Autor zaznacza, że w zachodnich diecezjach jedną z najważniejszych przyczyn powstawania kościołów filialnych była reformacja. Tam też świątynie pomocnicze stanowiły dość znaczny odsetek. Mniejsza liczba filii występowała w diecezjach wschodnich, niedotkniętych w takim stopniu reformacja, a dodatkowo majacych na swoim terenie cerkwie unickie. Powodami powstawania kościołów filialnych były również kwestie komunikacyjne: znaczne odległości od kościołów parafialnych, zły stan dróg oraz brak innych kościołów unickich. S. Litak, Parafie, s. 48-55.

${ }^{43}$ Atlas historyczny (arch)diecezii, s. 103; J. Kumor-Mielnik, Sieć, s. 168169; Obraz jeograficzno-statystyczny, s. 6.

${ }^{44}$ Tabella, t. 2, s. 301.

${ }^{45}$ Tamże, s. 134.

${ }^{46}$ Tamże, t. 1, s. 85

${ }^{47}$ Sytuacja Annopola została opisana w dalszej części tekstu. 
parafii. Trudności w zakresie analiz geograficzno-statystycznych generuje tutaj sama Tabella, nie podając informacji dotyczących okręgów filialnych. Analiza źródeł proweniencji kościelnej wskazuje na istnienie dwóch typów kościołów filialnych $-z$ okręgami parafialnymi i bez nich ${ }^{48}$. Możemy domniemywać, iż część z przedstawionych kościołów filialnych miała okręgi parafialne (można je określić jako filie parafialne), jednak zagadnienie to wymaga dodatkowych badań szczegółowych.

Kolejnym casusem jest przynależność parafialna miejscowości Łychów. Przypisano ją do parafii Rzeczyca Ziemiańska ${ }^{49}$, a ta $\mathrm{z}$ kolei widnieje jako podlegająca parafii Potok $^{50}$. Niejasna jest również przynależność parafialna miejscowości Pawlichy: Tabella podaje parafię Księżpol $^{51}$, który to znów przynależy do parafii Tarnogród ${ }^{52}$. Tak samo jest w przypadku miejscowości Huszczka Mała, która według Tabelli przynależy do parafii Manaster ${ }^{53}$, a ten - do parafii Szczebrzeszyn ${ }^{54}$. Przedstawione przykłady mogą świadczyć, że podczas opracowywania $T a-$ belli nie zadbano o zachowanie spójności opisu struktur kościelnych.

Opierając się na dotychczasowych badaniach omawianego okresu, możemy stwierdzić, że 31 parafii przytoczonych w opracowywanym źródle nie zostało dotychczas odnotowanych w literaturze. Są to: Babice, Biszcza, Bukowo, Chmielek, Chotcza, Józefów nad Wisłą, Kock, Korchów, Kossobudy, Księżpol, Kulno, Lipiny, Lipsko, Łosiniec, Majdan Księżopolski, Manaster, Ostrów, Ostrówek, Otrocz, Parczew, Potoczek, Siedliska, Sól, Stabrów, Sucha Wola, Terespól, Topolcza, Uhrusk, Wereszczyn i Zawichost ${ }^{55}$. Co istotne,

\footnotetext{
${ }^{48}$ Directorium horarum canonicarum et missarum pro dioecesi Vilnensi in annum Domini communem 1906, Vilnae 1905, s. 202.

${ }^{49}$ Tabella, t. 1, s. 288.

${ }^{50}$ Tamże, t. 2, s. 157.

${ }^{51}$ Tamże, s. 80.

${ }^{52}$ Tamże, s. 301

${ }^{53}$ Tamże, t. 1, s. 162.

${ }^{54}$ Tamże, t. 2, s. 8.

${ }^{55}$ Tamże, passim.

${ }^{56}$ W schematyzmach z 1870 r. tylko dwie z wymienionych wcześniej miejscowości należaty do parafii innej niż Kock: Węgielce (parafia Rudno) oraz Wierzchowiny (Czemierniki). Catalogus Universi Cleri Saecularis et Regularis Dioecesis Lublinensis Anno Domini 1870, Lublini 1870, s. $38-40$.
}

w obrębie granic tych parafii znajduje się aż 98 miejscowości. Tak duża liczba parafii pominiętych w innych opracowaniach może przeczyć hipotezie o błędzie edytorskim polegającym na nieprawidłowym zaklasyfikowaniu jednostek do okręgów parafialnych. Interesujący jest fakt, iż $7 \mathrm{z}$ wymienionych miejscowości parafialnych nie leżało na obszarze diecezji lubelskiej. Mowa tu o 5 parafiach należących do diecezji podlaskiej: $\operatorname{Kock}^{56}$ (dekanat międzyrzecki), Ostrów ${ }^{57}$, Parczew $^{58}$, Uhrusk i Wereszczyn (dekanat parczewski) oraz 2 znajdujących się na obszarze diecezji sandomierskiej: Chotcza (dekanat solecki) i Zawichost (dekanat Zawichost). Wymienione parafie wchodzące w skład diecezji podlaskiej do 1818 r. leżały w granicach diecezji lubelskiej" ${ }^{59}$. Opisana sytuacja może wskazywać, że Kościół łaciński nie realizował w pełni zaleceń administracji państwowej dotyczących dostosowania granic administracji kościelnej do państwowej. Inną przyczyną takiego stanu rzeczy może być duża intensywność zmian wprowadzonych $\mathrm{w} 1818 \mathrm{r}^{60}$ Znaczna ingerencja w świeckie i kościelne granice administracyjne mogła powodować, że administracja państwowa nie nadążała ze zmianami w aspekcie przynależności parafialnej poszczególnych miejscowości. Prostsza do zinterpretowania jest sytuacja dwóch pozostałych parafii, które nigdy nie były składowymi diecezji lubelskiej. Przynależność parafialna miejscowości należących do diecezji sandomierskiej wynikała prawdopodobnie z pomyłki edytora. Źródła późniejsze, jak choćby schematyzmy z 1870 r., informują, iż później miejscowości te nie należały do dwóch powyższych parafii ${ }^{11}$.

Powstaje pytanie, jak zinterpretować pozostałe 24 z 31 parafii, które nie pojawiały się w innych źródłach. Warto się zastanowić, czy autorzy Tabelli odnosili się wyłącznie do przynależności parafialnej w obrębie struktury administracyjnej

\footnotetext{
${ }^{57}$ Według danych z 1870 r. tylko Wólka Kijańska nie należała do parafii Ostrów.

${ }^{58} \mathrm{~W} 1870$ r. tylko Wola Tulnicka należała do parafii Parczew.

${ }^{59}$ J. Kumor-Mielnik, Sieć, s. 70.

${ }^{60}$ Zmiany przynależności parafialnej mające na celu dostosowanie granic administracji kościelnej do państwowej szczegótowo opisała Joanna Komor-Mielnik. Tamże, s. 168-169.

${ }^{61}$ Za indeksem w: Atlas historyczny (archi)diecezji, passim.
} 
Kościoła rzymskokatolickiego. Wydaje się wielce prawdopodobne, że w procesie przygotowywania materiału do omawianego opracowania pozyskano również informacje dotyczące struktury parafialnej obrządku greckokatolickiego. Może to potwierdzać fakt, że 14 z 24 wymienionych parafii to miejscowości parafialne unickiej diecezji chełmskiej: Babice, Biszcza, Chmielek, Korchów, Księżopól, Łosiniec, Majdan Księżopolski, Otrocz, Potoczek, Siedliska, Sól, Sucha Wola, Terespól i Topolcza ${ }^{62}$. W aspekcie przestrzennym zastanawiające jest również, że z 24 parafii aż 23 leżą na obszarze obwodu zamojskiego (mapa 1). W oparciu o dotychczasowy stan wiedzy niemożliwe jest ustalenie, z czego wynika taka koncentracja wątpliwych parafii.

Analiza przestrzenna danych ze źródła spisowego skorelowana ze źródłem kartograficznym nasuwa wątpliwości co do przynależności parafialnej poszczególnych miejscowości. Zastrzeżenia dotyczą m.in. 16 parafii, które obejmowały tylko jedną miejscowość: Bukowo, Grodek, Horyszów, Kiełczewice, Korchów, Lipiny, Łuszczów, Manaster, Ostrówek, Otrocz, Potoczek, Siedliska, Stabrów, Urzędów, Zawichost i Zemborzyce. Tylko $4 \mathrm{z}$ nich pojawiają się w innych źródłach i opracowaniach: Łuszczów, Kiełczewice, Urzędów i Zemborzyce ${ }^{63}$. Zastanawiający jest również fakt przynależności do okręgu parafialnego jednostek osadniczych znacznie oddalonych od stolicy parafii, czego przykładem mogą być Manaster i Annopol. W przypadku pierwszego źródło podaje przynależność do parafii Szczebrzeszyn ${ }^{64}$. W linii prostej Manaster jest oddalony o blisko $50 \mathrm{~km}$ od Szczebrzeszyna i oddzielony od niego trzema innymi okregami parafialnymi: Stary Zamość, Zamość i Nielisz. Wydaje się, że jest to błąd twórców źródła, gdyż miejscowość ta leży w zasięgu parafii Skierbie-

\footnotetext{
${ }^{62}$ Rocznik Instytutów, s. 167-176.

${ }^{63}$ Atlas historyczny, passim; J. Kumor-Mielnik, Sieć, passim.

${ }^{64}$ Tabella, t. 2, s. 8

${ }^{65}$ Catalogus Universi Cleri, s. 54.

${ }^{66}$ Obraz jeograficzno-statystyczny, s. 6.

${ }^{67}$ J. Kumor-Mielnik, Sieć, s. 168.

${ }^{68}$ Atlas historyczny (archi)diecezii, s. 76-78.

${ }^{69}$ Miejscowości: Giełczew, Kębtów, Kozice, Piaski, Siedliszczka, Siedziew i Wola Piasecka należały do obwodu lubelskiego, a Gardzienice i Wygnanowice - do krasnostawskiego.
}

szów i późniejsze zestawienia podają jej przynależność właśnie do tej parafii ${ }^{65}$. Annopol został przypisany w Tabelli do parafii Lubartów, od której oddalony jest w linii prostej o ponad 130 $\mathrm{km}$. W Obrazie jeograficzno-statystycznym figuruje zaś jako filia parafii Świeciechów ${ }^{66}$, co potwierdzają inne źródła i opracowania ${ }^{67}$.

Problemy związane z odtworzeniem struktury parafialnej na podstawie źródeł proweniencji świeckiej pozwalają zadać pytanie, czy informacje na temat rzeczywistej sytuacji w administracji kościelnej, którymi dysponowały instytucje państwowe, były aktualne. Na początku XIX w. władza rozpoczęła proces podporządkowywania sobie struktur administracji kościelnej, a przynajmniej wpływania na nie ${ }^{68}$. Należy zapytać, w jakim stopniu władza kościelna ulegała tym naciskom i w jakim zakresie władza świecka potrafiła nadzorować procesy unifikacyjne. Wątpliwości pojawiają się na przykład odnośnie do wydanego w 1819 r. nakazu o dostosowaniu granic dekanatów do obwodów. W kilku przypadkach granica obwodu nie pokrywała się z zasięgiem parafii, a więc także dekanatu. Zdarzało się, iż dzieliła ją na dwie części, np. parafia Piaski leżała w obwodach lubelskim i krasnostawskim ${ }^{69}$.

Weryfikację przynależności parafialnej okręgów parafialnych zawartych w Tabelli utrudnia brak źródeł proweniencji kościelnej z okresu jej powstania $^{70}$. Problemem jest fakt, że informacje o przynależności parafialnej w schematyzmach dla diecezji lubelskiej pojawiają się dopiero w zestawieniach z 1870 r. $^{71} \mathrm{Z}$ pewnością pomocne byłyby tu studia nad dziejami poszczególnych parafii, jednakże wykracza to poza zakres niniejszego opracowania. Mimo tych trudności i niewątpliwych błędów niekiedy Tabella wydaje się podawać informacje najbardziej wiarygodne, np. w przypadku miejscowości Szpikołosy ${ }^{72}$. W źródle występuje ona jako dwie odrębne jed-

\footnotetext{
${ }^{70}$ Prawdopodobnie były wtedy przeprowadzane wizytacje, ale wcześniejsze opracowania nie podają informacji o tego typu źródłach. Por. J. Kumor-Mielnik, Sieć, s. 271-288.

${ }^{71}$ Catalogus Universi Cleri.

72 Według informacji zawartych w Atlasie historycznym (archi)diecezji lubelskiej w 1870 r. Szpikołosy należały do parafii Hrubieszów. Atlas historyczny (archi)diecezji, s. 260.
} 
nostki osadnicze przynależące do dwóch różnych parafii - Horodło i Hrubieszów ${ }^{73}$. W rzeczywistości część osady (Szpikołosy Starościńskie) od czasu sprzedaży w $1800 \mathrm{r}^{74}$ znajdowała się w rękach prywatnych i od 1816 r. należała do Towarzystwa Rolniczego Hrubieszowskiego ${ }^{75}$.

Oprócz informacji określających przynależność parafialną miejscowości Tabella zawiera niezwykle cenne dane demograficzne i statystyczne. Umożliwia to przedstawienie statystyk dotyczących wielkości parafii. Największą pod względem liczby jednostek osadniczych była parafia Grabowiec skupiająca aż 38 miejscowości, a kolejną - Opole (37). Średnio na okręg parafialny przypadało 8,3 miejscowości. Pod względem liczby mieszkańców największą parafią był Hrubieszów $^{76}$ z 12220 osobami, najmniejszą zaś - Kiełczewice z 33577. Jedną parafię zamieszkiwało średnio ok. 2530 osób $^{78}$. Zastanawiająca jest stosunkowo duża liczba parafii nieintegralnych terytorialnie, w skład których wchodziły enklawy. Za przykład może posłużyć parafia Puszcza Solska, której terytorium przedzielone jest przez parafię Sól. Taka sama sytuacja dotyczy parafii Łaszczów oraz Dorohusk.

Rekonstrukcja przeprowadzona w oparciu o źródło spisowe i kartograficzne pozwoliła na bardzo precyzyjne wytyczenie granic podziałów administracyjnych $^{79}$. Zastosowanie rozwiązań z zakresu systemów informacji przestrzennej umożliwiło przeprowadzenie wstępnej krytyki

\footnotetext{
${ }^{73}$ Tabella, t. 2, s. 225.

${ }^{74}$ SGKP, t. 12, red. B. Chlebowski, W. Walewski, Warszawa 1977, s. 29.

75 J. Panasewicz, Materiaty do dziejów Towarzystwa Rolniczego Hrubieszowskiego w Archiwum Państwowym w Zamościu, „Archiwariusz Zamojski", 7, 2008, s. 91

${ }^{76}$ Największa liczba parafian przypada według Tabelli na Lublin, który zamieszkiwało 15597 osób. Niestety nie znajdujemy tam podziału na poszczególne parafie, stąd miasto nie zostało uwzględnione w statystyce.

${ }^{77}$ W statystyce nie uwzględniono dwunastu parafii obejmujących tylko jedną miejscowość, co do których istnieją wątpliwości.

${ }^{78}$ Przygotowując statystykę, autor bazował na liczbie 170 parafii podanych przez źródło.

${ }^{79}$ Wyznaczone granice mają charakter umowny i są interpretacją autorów projektu wynikającą z przyjętych założeń metodologicznych. Szerzej 0 wyznaczaniu granic zob. B. Szady, Granice powiatu łukowskiego w II połowie XVIII wieku - model liniowy i sieciowy, w: Narrata de fontibus hausta. Studia nad problematyką kościelną, polityczną i archiwistyczną ofiarowane Janowi Skarbkowi w siedemdziesiątą rocznice urodzin, red. A. Barańska, W. Matwiejczyk, Lublin 2010, s. 831-845

${ }^{80}$ Tabella, t. 2, s. 7.
}

źródła i ogólną konfrontację z dotychczasowym stanem badań. Pomimo wielu atutów Tabelli wydaje się, że nie można jej traktować jako jedynego źródła w zakresie odtworzenia struktury parafialnej na obszarze diecezji lubelskiej. Znaczący jest tutaj brak informacji o przynależności dekanalnej poszczególnych parafii, która pozwalałaby usystematyzować wiedzę. Krytyka źródła wykazała, iż zawiera ono wiele nieścisłości, które wymagają gruntownej analizy w toku dalszych badań. W świetle przeprowadzonej analizy liczbę 170 parafii należy pomniejszyć o 7 z siedzibą poza granicami województwa, 12 filii potraktowanych jako parafie oraz 14 będących prawdopodobnie parafiami unickimi. Dodatkowo z uzyskanych 137 okręgów parafialnych trzeba jeszcze odjąć okręg Manaster, który według Tabelli należy do parafii Szczebrzeszyn ${ }^{80}$. Z początkowej liczby pozostało zatem 136 okręgów parafialnych, co przewyższa dotychczasowe ustalenia o 9 jednostek. Niezweryfikowana jest przynależność parafii: Bukowo ${ }^{81}$, Horyszów ${ }^{82}$, Józefów ${ }^{83}$, Kossobudy ${ }^{84}$, Kulno ${ }^{85}$, Lipiny ${ }^{86}$, Lipsko $^{87}$, Ostrówek ${ }^{88}$ i Stabrów ${ }^{89}$. Konieczne wydaje się podjęcie w przyszłości prac, które pozwolą na szczególowe zweryfikowanie przyczyn występowania jednostek „nadliczbowych”.

Stworzona w ramach projektu baza danych pozwala na prowadzenie kolejnych pogłębionych studiów nad zgromadzonym materiałem. Wnikliwych rozważań wymaga proces

\footnotetext{
${ }^{81}$ Według źródła na obszarze diecezji lubelskiej nie istniało Bukowo. Wodległości 40 km od okręgu parafialnego leży miejscowość Bukowa należąca do okręgu parafialnego Sól. W Tabelli do parafii Bukowo przypisana jest tylko jedna miejscowość - Lipowiec.

82 Tabella, t. 1, s. 161.

${ }^{83}$ Tamże, s. 184. W omawianym czasie w Józefowie nad Wisłą oprócz kościoła parafialnego istniał jeszcze zakonny. Atlas historyczny, s. 103.

${ }^{84}$ Do parafii tej należą dwie miejscowości: Kossobudy oraz Wólka Nieprzecka. Tabella, t. 1, s. 230; t. 2, s. 284.

${ }^{85}$ Do parafii należą miejscowości: Kulno, Naklik i Szyszków. Tamże, t. 1, s. 243; t. 2, s. 39, 230.

${ }^{86}$ Tamże, t. 1, s. 267.

${ }^{87}$ Parafia obejmuje trzy miejscowości: Mokre, Pniówek i Wolę Lipską. Samo Lipsko należało według źródła do parafii Zamość. Tamże, t. 1, s. 266; t. 2, s. 30, 95, 277 .

${ }^{88}$ Do tej parafii należał tylko Żurawiniec, zaś Ostrówek - do parafii Kock. Tamże, s. 70, 366.

${ }^{89}$ Parafia obejmowała dwie miejscowości-Sulnice i Stabrów, oddzielone od siebie parafiami Skierbieszów i Sitaniec. Tamże, s. 210.
} 
powstawania źródła i proweniencja zawartych w nim danych dotyczących w głównej mierze przynależności parafialnej miejscowości. Być może pozwoli to w przyszłości na zweryfikowanie stanu wiedzy ówczesnych władz świeckich o administracji kościelnej. Niezwykle ważny jest postulat badawczy dotyczący przebiegu północno-wschodniej granicy województwa lubelskiego. Na obszarze tym zidentyfikowano najwięcej miejscowości należących do okręgów parafialnych, które nie wchodziły w skład diecezji lubelskiej. Na podstawie dotychczasowych ustaleń nie można jednoznacznie skomentować rozbieżności pomiędzy analizowanym źródłem, mapą Kwatermistrzostwa i dotychczasowym stanem badań. Analiza przestrzenna nieścisłości pokazuje, iż występują one w zauważalnych koncentracjach, co wymaga dodatkowych studiów.

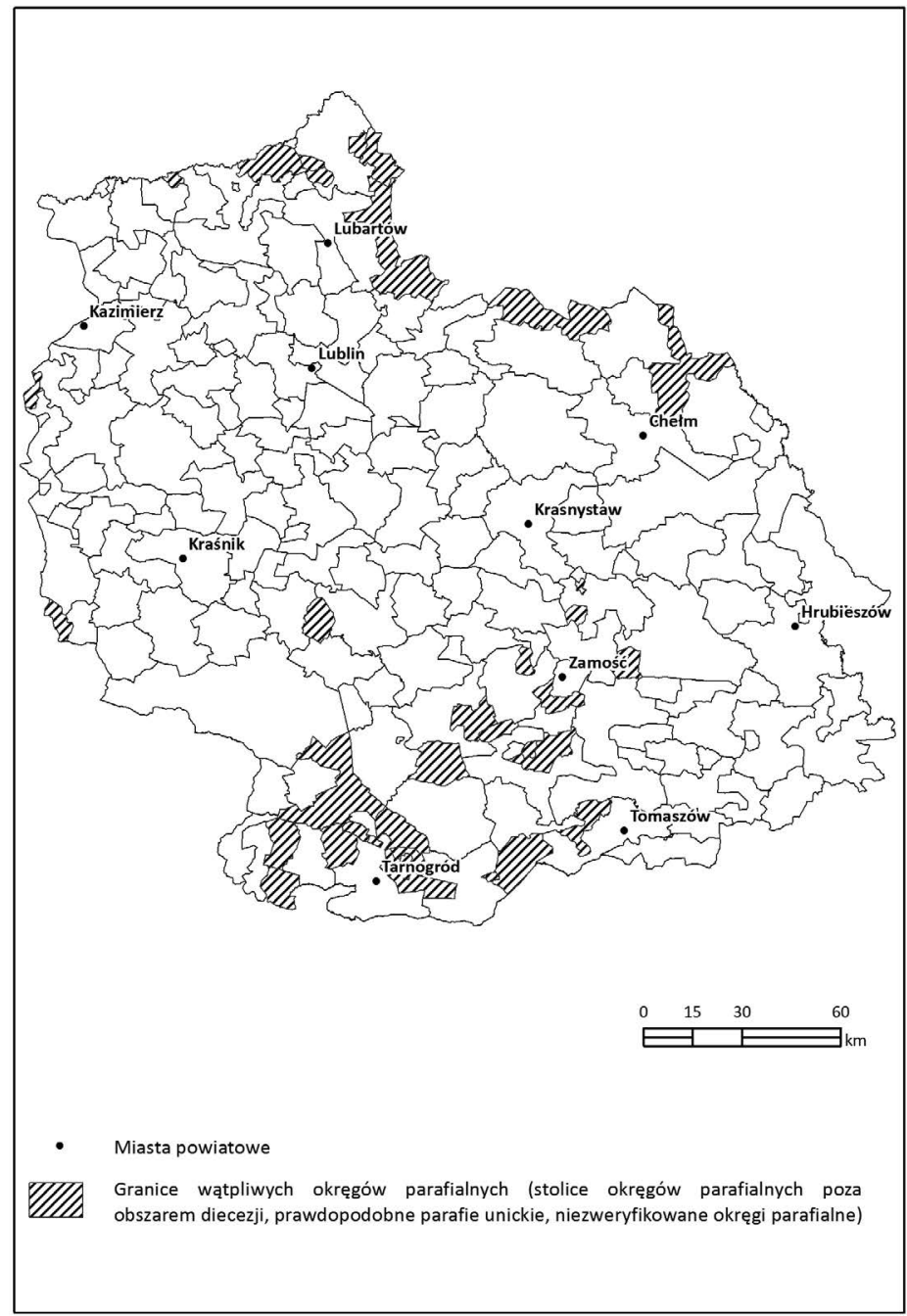

Mapa 1. Granice okręgów parafialnych diecezji lubelskiej według „Tabelli” 


\section{Bibliografia}

Arnold S., Terytorja plemienne w ustroju administracyjnym Polski Piastowskiej (w. XII-XIII), Kraków 1927.

Atlas historyczny (archi)diecezji lubelskiej 1805-2010, red. H. Gapski, Lublin 2011.

Borkiewicz A., Trzebiński W., Podziaty administracyjne Królestwa Polskiego w okresie 1815-1918 r., Warszawa 1956 (Dokumentacja Geograficzna, 4).

Ćwik W., Reder J., Lubelszczyzna: dzieje rozwoju terytorialnego, podziatów administracyjnych $i$ ustroju wtadz, Lublin 1977.

Historia Polski w liczbach. Ludność. Terytorium, Warszawa 1994.

Jelonek A., Ludność miast i osiedli typu miejskiego na ziemiach Polski od 1810 do 1960 r., Warszawa 1967 (Dokumentacja Geograficzna, 3-4).

Kołłątaj H., Listy Anonima $i$ prawo polityczne narodu polskiego, t. 2, oprac. B. Leśniodorski, H. Wereszczycka, Kraków 1953.

Krassowski B., Topograficzna karta Królestwa Polskiego (1822-1843), Warszawa 1978.

Kumor B., Diecezja lubelska (180 lat istnienia), „Wiadomości Diecezjalne Lubelskie", 59 (5-7), 1985, s. $234-240$.

Kumor B., Granice metropolii i diecezji polskich (9661939), „Archiwa, Biblioteki i Muzea Kościelne”, 20 (1), 1970, s. 253-374.

Kumor B., Ustrój i organizacja Kościota polskiego wokresie niewoli narodowej 1772-1918, Kraków 1980.

Kumor-Mielnik J., Sieć dekanalna i parafialna (archi)diecezji lubelskiej $w$ latach 1805-2005, Lublin 2011.

Litak S., Atlas Kościota tacińskiego w Rzeczpospolitej Obojga Narodów w XVIII wieku, Lublin 2006.

Litak S., Kościót tacinski w Rzeczpospolitej okoto 1772 roku. Struktury administracyjne, Lublin 1996.

Litak S., Parafie w Rzeczpospolitej $w$ XVI-XVIII wieku, Lublin 2004.

Litak S., Struktura terytorialna Kościota tacińskiego w Polsce w 1772 roku, Lublin 1980.
Nazwy miejscowe Polski: historia, pochodzenie, zmiany, red. K. Rymut, t. 2: $C-D$, Kraków 1997.

Panasewicz J., Materiaty do dziejów Towarzystwa Rolniczego Hrubieszowskiego w Archiwum Państwowym w Zamościu, „Archiwariusz Zamojski”, 7, 2008, s. 91-100.

Radecki F., Obraz jeograficzno-statystyczny Królestwa Polskiego, Warszawa 1830.

Rymut K., Nazwy miast Polski, Wrocław-WarszawaKraków-Gdańsk-Łódź 1987.

Rzetelska-Feleszko E., Nazwy miejscowe, w: Polskie nazwy wtasne. Encyklopedia, red. E. Rzetelska-Feleszko, Warszawa-Kraków 1998, s. 191-230.

Stownik geograficzny Królestwa Polskiego i innych krajów stowiańskich, t. 7, red. B. Chlebowski, W. Walewski, Warszawa 1886.

Stownik geograficzny Królestwa Polskiego i innych krajów stowiańskich, t. 12, red. B. Chlebowski, W. Walewski, Warszawa 1977.

Stownik historyczno-geograficzny ziem polskich $w$ średniowieczu, red. T. Jurek (http://www.slownik.ihpan.edu.pl/search.php?id=10209, dostęp: 17 października 2016).

Szady B., Granice powiatu tukowskiego w II potowie XVIII wieku - model liniowy i sieciowy, w: Narrata de fontibus hausta. Studia nad problematyka kościelna, polityczna $i$ archiwistyczna ofiarowane Janowi Skarbkowi $w$ siedemdziesiąta rocznice urodzin, red. A. Barańska, W. Matwiejczyk, Lublin 2010, s. 831-845.

Tyszkiewicz J., Geografia historyczna. Zarys problematyki, Warszawa 2014.

Warchoł S., Nazwy miast Lubelszczyzny, Lublin 1964.

Wojciechowski S., Atlas historyczny Polski. Województwo lubelskie w drugiej potowie XVI wieku, Warszawa 1966.

Wójcik U., O sposobach badania nazw wtasnych (przesztość, teraźniejszość, przysztość), „Prace Naukowe Akademii im. Jana Długosza w Częstochowie. Językoznawstwo", 11, 2015, s. 153-162. 


\section{The "Tabella of Towns, Villages and Settlements of the Kingdom of Po- land" as the Source for Research into the Parochial Structure of the Lublin Voivodeship}

\section{Summary}

The present article is an attempt to assess the usefulness of the Tabella of Towns, Villages and Settlements of the Kingdom of Poland for the purposes of research into parochial structures. Studies aimed at a reconstruction of parochial districts have abounded in Polish historiography. The vast majority of them referred to periods for which sources of a church provenience were available. What strikes in expert literature is the lack of representation of the parochial districts of the Lublin diocese from the $1^{\text {st }}$ half of the $19^{\text {th }} \mathrm{c}$., which most probably stems from the lack of church provenience sources for that period. Here, with reliance on geographical-historical and statistical analysis the author attempted to verify the information included in the present source. Tabella was compared and contrasted with Quartermaster map and contemporary publications. The process enabled the author to verify the source, allowing, too, for quite a meticulous reconstruction of the borders of state and church administration. Apart from information on a given location's administrative affiliation, the investigated source includes very valuable demographic and statistical data. However, the critique of the source revealed its many flaws and imprecisions which call for extended scrutiny and research. In particular, what needs to be clarified, is the numerosity of the parish whose value diverges from the hitherto established values. The Tabella's inaccuracy refers also to toponomastic errors and erroneous information related to parochial affiliations. All in all, despite the Tabella's many assets, the author's conclusion is that it cannot be relied upon as the singular source for reconstructing parochial structures of the Lublin diocese in the $1^{\text {st }}$ half of the $19^{\text {th }} \mathrm{c}$.

Słowa kluczowe : diecezja lubelska, okręgi parafialne, administracja terytorialna, Kościół rzymskokatolicki, województwo lubelskie w XIX w., geografia historyczna

Keyw ord s: the Lublin diocese, parochial districts, territorial administration, the Roman Catholic Church, the Lublin voivodeship in the $19^{\text {th }}$ century, historical geography

mgr Mateusz Zawadzki - absolwent historii, doktorant na Wydziale Nauk o Ziemi i Gospodarki Przestrzennej UMCS.

Specjalista w zakresie systemów informacji przestrzennej. Zajmuje się geografią historyczną oraz historią kartografii. Przygotowuje rozprawę doktorską na temat rozwoju sieci drożnej województwa lubelskiego w okresie nowożytnym (mateusz.zawadzki5@gmail.com) 